This is a pre-copyedited, author-produced version of an article accepted for publication in Twentieth Century British History following peer review. The version of record, Brett Holman, 'The shadow of the airliner: commercial bombers and the rhetorical destruction of Britain, 1917-35', Twentieth Century British History 24 (2013), 495-517, is available online at: https://doi.org/10.1093/tcbh/hws042.

\title{
The shadow of the airliner: commercial bombers and the rhetorical destruction of Britain, 1917-1935 ${ }^{1}$
}

Brett Holman, Independent Scholar

\begin{abstract}
Aerial bombardment was widely believed to pose an existential threat to Britain in the 1920s and 1930s. An important but neglected reason for this was the danger from civilian airliners converted into makeshift bombers, the so-called 'commercial bomber': an idea which arose in Britain late in the First World War. If true, this meant that even a disarmed Germany
\end{abstract}

\footnotetext{
${ }^{1}$ The author would like to thank: the referees, for their detailed comments; Chris A. Williams, for his assistance in locating a copy of Cd. 9218; and, for their comments on a draft version of this article, Alan Allport, Christopher AmanoLangtree, Corry Arnold, Katrina Gulliver, Wilko Hardenberg, Lester Hawksby, James Kightly, Beverley Laing, Ross Mahoney, Andre Mayer, Bob Meade, Andrew Reid, and Alun Salt. Figure 1 first appeared in the Journal of the Royal Institute of International Affairs, Vol, 8, No. 4, July 1929, pp, 289-317, and is reproduced with permission.
} 
could potentially attack Britain with a large bomber force thanks to its successful civil aviation industry. By the early 1930s the commercial bomber concept appeared widely in British airpower discourse. Proponents of both disarmament and rearmament used, in different ways and with varying success, the threat of the commercial bomber to advance their respective causes. Despite the technical weakness of the arguments for convertibility, rhetoric about the commercial bomber subsided only after rearmament had begun in earnest in 1935 and they became irrelevant next to the growth in numbers of purpose-built bombers. While the commercial bomber was in fact a mirage, its effects on the disarmament and rearmament debates were real.

Keywords: civil aviation, aerial bombardment, disarmament, rearmament

\section{Introduction}

At the start of March 1935, elements of the Greek armed forces attempted a coup in favour of former prime minister Eleftherios Venizelos, ostensibly in defence of the Hellenic Republic against a restoration of the monarchy. ${ }^{2}$ A number of rebel warships fled to Crete, and loyalists concentrated all available aircraft to attack

\footnotetext{
${ }^{2}$ For background on the March 1935 coup, which ultimately failed, see Ioannis S. Koliopoulos, 'The last years, 1933-6', in Paschalis M. Kitromilides (ed.), Eleftherios Venezelios: The Trials of Statesmanship (Edinburgh, 2006), 240-3.
} 
them. According to the London Evening News, in its desperation the Greek government even 'mobilised the Junker [sic] passenger planes that fly between Athens and Salonica to use them in attacking the rebel fleet'. One headline read 'PASSENGER PLANES MOBILISED FOR WAR'. ${ }^{3}$ Lest readers miss the significance of this, the newspaper devoted its leading article to what it called 'The commercial bomber'. Describing this as 'the first recorded instance of civil aircraft being commandeered for military purposes'-though 'It will not be the last'-the Evening News went on to explain the significance of this event:

it proves to the hilt what the advocates of a bigger British Air Force have consistently maintained, that calculations of a nation's air strength are illusory unless they take into consideration the number of civilian planes on which it can at any given moment lay hands.

In 'the next war', it claimed, air forces would be greatly strengthened by the addition of these ersatz bombers. The conclusion was clear: 'The more commercial planes this country has and the more readily convertible they are into bombers the better off we shall be. ${ }^{4}$

There appears to be no evidence that the Greek government ever did use its airliners to bomb the rebel warships. ${ }^{5}$ But for the Evening News this didn't

\footnotetext{
${ }^{3}$ London Evening News (London), 4 March 1935, 1. The Junkers G24 was a German three-engined airliner which first flew in 1924. It could carry up to 14 passengers, and won export orders from a dozen countries.

${ }^{4}$ London Evening News, 4 March 1935, 8.

${ }^{5}$ The conversion of the Greek airliners was also noted in Manchester Guardian,
} 
matter: the mere possibility played into its airminded agenda. ${ }^{6}$ For a month it had been running a series of articles on readers' stories of the German air raids on Britain during the Great War. It and other publications from Lord Rothermere's group of politically conservative newspapers, including the high-circulation Daily Mail, also reported extensively on the recruiting drive of the National League of Airmen, a populist advocacy group founded by Rothermere with the purpose of forcing the Government to expand the Royal Air Force (RAF). ${ }^{7}$ And the day after the story of the Greek commercial bombers broke, the Evening News denounced an increase of $£ 3$ million in the air estimates as 'paltry'. ${ }^{8}$ In his campaign for a bigger air force, Rothermere's most powerful rhetorical weapon was 'the shadow

4 March 1935, 9; Daily Express, 4 March 1935, 2; Flight, 7 March 1935, 245. None of these sources mentions their use in combat.

${ }^{6}$ On the phenomenon of airmindedness, that is an evangelical enthusiasm for aviation, see David Edgerton, England and the Aeroplane: An Essay on a Militant and Technological Nation (Basingstoke, 1991); Robert Wohl, The Spectacle of Flight: Aviation and the Western Imagination, 1920-1950 (Melbourne, 2005); Peter Adey, “"Ten thousand lads with shining eyes are dreaming and their dreams are wings": affect, airmindedness and the birth of the aerial subject', Cultural Geographies, 18 (2011), 63-89.

${ }^{7}$ Rothermere, My Fight to Rearm Britain (London, 1939), 89-96; Paul Addison, 'Patriotism under pressure: Lord Rothermere and British foreign policy', in Gillian Peele and Chris Cook (eds), The Politics of Reappraisal, 1918-1939 (London and Basingstoke, 1975), 189-208.

${ }^{8}$ London Evening News, 5 March 1935, 1; Brett Holman, 'The air panic of 1935: British press opinion between disarmament and rearmament', Journal of Contemporary History, 46 (2011), 288-307. 
of the bomber'-the widespread fear of a knock-out blow from the air, a sudden overwhelming aerial attack against London and other cities using high explosive bombs, incendiary weapons and poison gas, which would kill untold thousands of civilians and force Britain to capitulate to its enemy within only weeks or even days of the initial attack. ${ }^{9}$ The possible conversion of airliners into bombers gave any nation with a substantial civil aviation industry a powerful striking force in waiting regardless of the actual size of its professional air force, thus amplifying the danger of a knock-out blow. This amplification, as it turned out, was more rhetorical than real.

The concerns about convertibility, though exaggerated, were not baseless. The first airliners after the First World War were simply converted from bombers like the Vickers Vimy. RAF air transports were turned into ersatz bombers in Iraq in 1922; some later aircraft like the Bristol Bombay were designed to perform a dual transport-bomber role. ${ }^{10}$ Italy announced in 1928 that in future its civil

\footnotetext{
${ }^{9}$ Uri Bialer, The Shadow of the Bomber: The Fear of Air Attack and British Politics, 1932-1939 (London, 1980); Susan Grayzel, Air Raids and Culture in Britain from the Great War to the Blitz (New York, 2012); Brett Holman, 'The Next War in the Air: Civilian Fears of Aerial Bombardment in Britain, 19081941', PhD thesis, University of Melbourne, 2009. For Rothermere's beliefs about airpower see Patrick Glenn Zander, 'Right Modern: Technology, Nation, and Britain's Extreme Right in the Inter-war Period (1919-1940)', PhD thesis, Georgia Institute of Technology, 2009, 268-76.

${ }^{10}$ Henry Probert, Bomber Harris: His Life and Times (London, 2001), 52-3.
} 
aircraft would be built with convertibility in mind. ${ }^{11}$ Similarly, seven Airspeed Envoy airliners procured by the South African State Railways featured fittings for external bomb-racks; the roof over the toilet compartment was designed to be replaced by a gun turret if required. ${ }^{12}$ Both sides in the Spanish Civil War scoured Europe for civilian aircraft capable of being pressed into combat use. ${ }^{13}$ The RAF used militarised versions of civilian aircraft early in the Second World War, such as the Lockheed Hudson, based on the successful Electra airliner. Most attention, though, focused on the potential German use of commercial bombers, since under the Versailles treaty it was forbidden any military aircraft at all even while its civil aviation industry was progressing by leaps and bounds. In the late 1920s and early 1930s, the German national airline Deutsche Luft Hansa did have strong ties with the still-secret Luftwaffe, providing many of its early leaders like Dr Robert Knauss and Erhard Milch. ${ }^{14}$ Many of the nascent air force's first aircraft were civilian aircraft pressed into military service-albeit ones which had been expressly designed with use as bombers, fighters or trainers in mind. And until 1935 German mobilisation plans did in fact allow for the conversion of civilian aircraft into

${ }^{11}$ Daily Mail, 30 May 1928, 5.

${ }^{12}$ Nevil Shute, Slide Rule: The Autobiography of an Engineer (London, 2009 [1954]), 229.

${ }^{13}$ Shute, Slide Rule, 232-3.

${ }^{14}$ James S. Corum, The Luftwaffe: Creating the Operational Air War, 19181940 (Lawrence, 1997), 130-4. In 1933, Deutsche Luft Hansa changed its name to Deutchse Lufthansa or simply Lufthansa. 
commercial bombers in an emergency. ${ }^{15}$ In 1931, French intelligence estimates put the number of German civilian aircraft capable of conversion to military use within eight to ten days at 400, around twice the number of bombers the RAF had based in Britain. ${ }^{16}$ But while the Luftwaffe used militarised versions of the Junkers Ju 52 airliner to bomb towns and cities from Guernica to Warsaw, these were not ad hoc conversions. The Greek government's hastily modified Junkers G24s are perhaps the closest true commercial bombers came to ever existing. Their real significance lies in their effect on the way people thought about airpower.

Commercial bombers appear again and again in the literature written in the 1920s and 1930s about the future of aerial warfare, yet hardly at all in the most important secondary literature devoted to the subject. References are sometimes made to contemporary concerns about the militarisation of civil aviation, but just what these concerns were is rarely explained. ${ }^{17}$ These lacunae are the result of a

${ }^{15}$ Edward Homze, Arming the Luftwaffe: The Reich Air Ministry and the German Aircraft Industry, 1919-1939 (Lincoln and London, 1976), 13, 26, 2930, 32-3.

${ }^{16}$ Homze, Arming the Luftwaffe, 32; John James, The Paladins: A Social History of the RAF up to the Outbreak of World War II (London and Sydney, 1990), 249. ${ }^{17}$ For example, see the brief mentions in George F. Quester, Deterrence before Hiroshima: The Airpower Background of Modern Strategy (New Brunswick and Oxford, 1986 [1966]), 67; Malcolm Smith, British Air Strategy Between the Wars (Oxford, 1984), 116; Tami Davis Biddle, Rhetoric and Reality in Strategic Air Warfare: The Evolution and Reality of British and American Ideas about Strategic Bombing, 1914-1945 (Princeton and Oxford, 2002), 108. Most 
number of factors. As it turned out, converted airliners did not make very effective bombers and were of little consequence during the Second World War. For that matter, the fear of a knock-out blow itself was vastly exaggerated and is therefore often regarded as an distraction from the actual bomber war. ${ }^{18}$ The commercial

research has centred on the diplomatic ramifications of convertibility, particularly with respect to the World Disarmament Conference in 1932-4. See David Carlton, 'The problem of civil aviation in British air disarmament policy, 1919-1934', Journal of the Royal United Service Institution, 111 (1966), 307-16; Phillip S. Meilinger, 'Clipping the bomber's wings: the Geneva Disarmament Conference and the Royal Air Force, 1932-1934', War in History, 6 (1999), 30630; N.C. Fleming, 'Cabinet government, British imperial security, and the World Disarmament Conference, 1932-1934', War in History, 18 (2011), 62-84. Another historiographical strand relates to proposals for an international air force, which usually provided for the control of civil aviation. See Waqar H. Zaidi, "“Aviation will either destroy or save our civilization": proposals for the international control of aviation, 1920-45', Journal of Contemporary History, 46 (2011), 150-78; Brett Holman, 'World police for world peace: British internationalism and the threat of a knock-out blow from the air, 1919-1945', War in History, 17 (2010), 313-32. The only attempt to assess the broader influence of the commercial bomber idea is Barry Powers, Strategy Without Slide-Rule: British Air Strategy 1914-1939 (London, 1976), 115-9. Because there is no adequate term in the existing literature, I am here introducing 'commercial bomber' as a general term for the rapid, ad hoc conversion of civilian aircraft into bombers. It was not used widely in the primary sources, which generally use clumsy or barely evocative phrases.

${ }^{18}$ For example, Robin Neillands, The Bomber War: Arthur Harris and the Allied Bomber Offensive 1939-1945 (London, 2001). 
bomber is also neglected because the concept of arming airliners is today so foreign that the pervasive references in inter-war airpower discourse to the threat of civil aviation are easily confused with the use of militarised versions of civilian types or with reserves of civilian pilots. ${ }^{19}$ But while the reality of the commercial bomber failed to match expectations, nevertheless those expectations shaped belief and behaviour: the reality of a threat is far less important in creating fear than the perception of it. ${ }^{20}$ This is all the more so when that threat is technological in nature and so escalates as the pace of technological change increases, as was the case with aviation technology after the First World War. ${ }^{21}$ When combined with a belief in the certainty of a knock-out blow from the air, the principle of convertibility meant that even with Germany disarmed, its strength in civil aviation meant that it still posed a grave threat to Britain; or at least appeared to.

David Edgerton argues that war has been written out of the historiography of British technology, aviation especially. He is correct to challenge the widespread and implicit historiographical tendency to treat 'aviation under transportation, and military aviation within the larger context of civilian

${ }^{19}$ For example, Neville Jones, The Beginnings of Strategic Air Power: A History of the British Bomber Force 1923-1939 (London, 1987), 25-6, 50.

${ }^{20}$ Eric Goode and Nachman Ben-Yehuda, Moral Panics: The Social

Construction of Deviance (Oxford and Cambridge, 1994), 36-8. Generally, see Joanna Bourke, Fear: A Cultural History (London, 2005); Corey Robin, Fear: The History of a Political Idea (Oxford and New York, 2004).

${ }^{21}$ Philip Jarrett (ed.), Biplane to Monoplane: Aircraft Development 1919-39 (London, 1997). 
aviation'.22 In fact, the prevalence of the commercial bomber idea shows that civilian and military aviation were often thought of as entangled, if not quite indivisible, and we need to understand this. As will be shown below, post-war attempts from inside and outside the RAF to turn Britain into an aerial 'nation at arms' dependent on convertible airliners failed; instead the model of a small but fully professional air force prevailed. As will also be shown, however, the parallel efforts to portray France and Germany as just such aerial nations at arms were much more successful. ${ }^{23}$ The implication was that by failing to integrate its civil and military aviation in like fashion, Britain lacked the airpower to deter its destruction. The commercial bomber was a rhetorical weapon in the battle to make Britain airminded. ${ }^{24}$

\section{The Civil Aerial Transport Committee and the Sykes memorandum}

The First World War was the making of British aviation. Britain began it with only a few dozen military aircraft and little capacity to produce more. By the third year of the war it possessed more than a thousand frontline aeroplanes and the largest aviation industry in the world. ${ }^{25}$ Even though the war clearly was a long

22 David Edgerton, Warfare State: Britain, 1920-1970 (Cambridge, 2006), 316.

${ }^{23}$ See Andrew Barros, 'Razing Babel and the problems of constructing peace:

France, Great Britain, and air power, 1916-28', English Historical Review, 126 (2011), 75-115.

${ }^{24}$ On rhetoric in airpower thought, see Biddle, Rhetoric and Reality, 6-7.

${ }^{25}$ John H. Morrow, The Great War in the Air: Military Aviation from 1909 to 
way from ending, due to the increased importance of the aviation industry the government began to consider how to manage the transition to peace, especially given the inevitable precipitous fall in military orders upon which aircraft manufacturers had come to depend. In May 1917, the Air Board, the government body then responsible for coordinating air policy, formed the Civil Aerial Transport Committee (CATC) with a brief to consider the development of civil aviation after the war. The CATC brought aeroplane designers and airpower advocates together with representatives of the armed forces, the Dominions, and various government ministries-and the ubiquitous H.G. Wells, known for, among other works, his prophetic novel The War in the Air. ${ }^{26}$ It made recommendations on such topics as imperial air routes, the need for air safety regulations, and the employment of many thousands of experienced aviators and war-surplus aeroplanes. $^{27}$

Despite its pacific name, the CATC also touched on more martial matters. In its final report of February 1918, the committee examined probable

1921 (Washington, D.C., and London, 1993), 236, 251.

${ }^{26}$ H.G. Wells, The War in the Air and Particularly how Mr Bert Smallways Fared while it Lasted (London, 1908); Michael Paris, Winged Warfare: The Literature and Theory of Aerial Warfare in Britain, 1859-1917 (Manchester, 1992), 33-9.

${ }^{27}$ Robin Higham, Britain's Imperial Air Routes 1918 to 1939: The Story of Britain's Overseas Airlines (London, 1960), 20-3; Gordon Pirie, Air Empire: British Imperial Civil Aviation (Manchester and New York, 2009), 12-5. 
developments in civil aviation from a 'commercial point view', but recognised that 'military considerations must override all others'. It predicted that the ideal commercial aeroplane would have a high speed, a long range and a large capacity for cargo. But as the present war had shown, these were also the characteristics of the ideal bomber. The CATC therefore recorded its 'strong opinion that it is vitally necessary, in the interests of national safety ... that the development and manufacture of types of commercial aircraft should for a long time be governed by the requirement that they should be in some manner of effective military use', even at the expense of profitability. ${ }^{28}$ What this might mean in practice for Britain's future air policy was left largely unexplored. The only hint came in a critical minority statement by Frank Pick, commercial manager of the London Underground, who suggested that relying on convertibility for airpower would require the continuous maintenance of 'large [civilian] fleets of partially serviceable [in military terms] aircraft' ${ }^{29}$

When the CATC's report was belatedly published in December 1918, less than a month after the Armistice, The Times emphasised 'the need for the rapid convertibility ... of some types of commercial aircraft to military uses' by quoting the committee's recommendation on this point in full. On the same page it ominously reported that Germany was already beginning air services between

${ }^{28}$ Reports of the Civil Aerial Transport Committee with Appendices, Cd. 9218 (1918), 11.

${ }^{29}$ Cd. $9218,18$. 
major cities; and that furthermore the Schütte-Lanz company-until recently better known for building airships used to bomb Britain-was 'constructing a new large type of aeroplane able to carry 40 passengers'. The implication was that the anticipated 'world-race' in civil aviation had already begun, and that defeated Germany was using its industrial prowess to steal a march on an unsuspecting Britain. ${ }^{30}$

Despite the CATC's recommendations and the endorsement of influential newspapers, at war's end Lloyd George's government decided that British airpower was not to rely upon convertible civil aircraft in any way. This was not for want of effort on the part of Brigadier-General Frederick Sykes, Chief of the Air Staff (CAS) and hence professional head of the RAF (formed in April 1918 partly in response to the shocking German bomber raids on London the previous year). ${ }^{31}$ With the Armistice now in effect and peace in the offing, Sykes prepared a plan for the organisation and role of the post-war RAF - the infamous 'Sykes memorandum', which was to cost the CAS his job due to its financial extravagance. ${ }^{32}$ Sykes initially proposed retaining the bulk of the force built up over four years of war in a large peacetime RAF of 157 squadrons, mostly cadres

${ }^{30}$ The Times, 9 December 1918, 4.

${ }^{30}$ Powers, Strategy Without Slide-Rule, 90-3.

32 'Memorandum by the Chief of the Air Staff on air-power requirements of the Empire', 9 December 1918 (Sykes memorandum), in Frederick Sykes, From Many Angles: An Autobiography (London. 1942), 558-74. See also Powers, Strategy Without Slide-rule, 161-2. 
to facilitate rapid expansion, and oriented towards Imperial and army cooperation. This included a 'striking force' of 20 squadrons, the wartime objective of which would be the "nerve centres, the armies and navies of the opponent, the population as a whole, his national moral, and the industries, without which he cannot wage war'.33

Sykes placed a great weight on a strong civil aviation industry, foreseeing the need for subsidies and other forms of government support to ensure the viability of British airlines. This would help keep aircraft manufacturers in business, foster an extensive network of air routes and aerodromes across the Empire, and provide a pool of experienced pilots and mechanics for the RAF to draw upon in the event of war. Sykes also proposed using civilian aircraft as makeshift combat aircraft. To this end, his plan required that suitable airliners and transports be 'fitted for the installation of the necessary armament which would be maintained in readiness' as a ready reserve. ${ }^{34}$ By replacing combat wastage with converted airliners in this way, Britain would be able to maintain a much bigger striking force in war than it could afford to maintain in peace. But even though it was designed to provide great offensive power at low cost, Sykes's plan was still too expensive for a government eager to return to pre-war norms of expenditure. Early in 1919, the new Air Minister, Winston Churchill, therefore

\footnotetext{
${ }^{33}$ Sykes memorandum, in Sykes, From Many Angles, 561. 'Moral' was an alternative form of 'morale', taken from the French.

${ }^{34}$ Sykes memorandum, in Sykes, From Many Angles, 572.
} 
replaced Sykes with his predecessor, Major-General Hugh Trenchard. ${ }^{35}$ The reinstated CAS worked out an alternative and much cheaper scheme focused on long-term institution building and only a limited operational capability. Given that the RAF had been in existence for less than a year, this was a judicious move in terms of securing the junior service's independence against the jealousy of the Army and the Royal Navy. But when Trenchard's plan was eventually published in December 1919, it had only 82 squadrons - and no place for civil aviation at all..$^{36}$

\section{P.R.C. Groves and 'Our future in the air'}

Some disquiet at the rejection of the Sykes memorandum did appear in the press and in military journals. In January 1920, for example, an anonymous 'ExSquadron Commander' wrote to The Times luridly describing how Germany's civil air fleet would one day 'suddenly appear in their tens of thousands above us and ... rain down chemicals and bombs' upon London until it was 'utterly destroyed'. He believed that the only way to prevent this was for Britain to possess its own 'fleet of commercial machines' to give it the ability to visit 'a swift and terrible retribution ... upon the enemy's main centres of activity', but was worried

${ }^{35}$ Eric Ash, Sir Frederick Sykes and the Air Revolution, 1912-1918 (London and Portland, 1999), 174-7

${ }^{36}$ John Robert Ferris, Men, Money and Diplomacy: The Evolution of British Strategic Foreign Policy, 1919-26 (Ithaca, 1989), 68-9. 
by signs that its aviation industry was declining rapidly while Germany's was progressing in leaps and bounds. But such prophets had little influence and were soon forgotten. ${ }^{37}$

The same cannot be said about General P.R.C. Groves, a former RAF staff officer who by the mid-1930s was perhaps the most prominent writer on the danger posed to Britain by bombing. ${ }^{38} \mathrm{He}$ first attracted national attention early in 1922 by penning a series of articles for The Times under the general title 'Our future in the air'. Here, he was the first to truly succeed in popularising the theory of the knock-out blow from the air, itself a product of the Great War. ${ }^{39}$ Crucially, his exposition depended heavily on the idea of the commercial bomber. This is not surprising, for Groves was a friend and acolyte of Sykes who had served as his Director of Flying Operations in 1918 and helped to draft the CAS's ill-fated

\footnotetext{
${ }^{37}$ The Times, 23 January 1920, 8. See also Louis Jackson, 'Possibilities of the next war', Journal of the Royal United Service Institution, 65 (February 1920), 71-89.

${ }^{38}$ Robin Higham, The Military Intellectuals in Britain: 1918-1939 (Westport, 1966), 170-5. Groves's courtesy rank at retirement from the RAF was brigadiergeneral, usually shortened to general.

${ }^{39}$ Holman, 'The Next War in the Air', 49-66. The first appearance of the knockout blow proper was during the war, though it was little remarked on at the time: Claude Grahame-White and Harry Harper, 'Two years of aerial war', Fortnightly Review, 100 (August 1916), 195-210; Claude Grahame-White and Harry Harper, Air Power: Naval, Military, Commercial (London, 1917).
} 
memorandum. ${ }^{40} \mathrm{He}$ attended the Peace Conference as Sykes's deputy and stayed on in Paris to serve as British representative on the Inter-Allied Aeronautical Commission of Control, the body which oversaw Germany's aerial disarmament. He also represented Britain on aviation matters at the League of Nations. ${ }^{41}$ In these diplomatic capacities, Groves was vocal in warning that 'the military brain of Germany intends to develop German airpower under camouflage of civil aviation', as he put it in a letter to the Under-Secretary for Air, Major-General J.E.B. Seely. ${ }^{42}$ But eventually his superiors ceased to listen to him, and at Paris and Geneva he was forced to toe the Air Ministry's line by downplaying the danger of convertibility. Frustrated at his inability to influence the government's air policy, Groves resigned from the RAF towards the end of 1921. In an unpublished book written just before the outbreak of the Second World War, Groves wrote that his ideas about the nature of airpower 'were so irreconcilable

${ }^{40}$ P.R.C. Groves, Behind the Smoke Screen (London, 1934), 252-3; Liddell Hart Centre for Military Archives, King's College London, P.R.C. Groves papers (hereafter Groves papers), 5(e), P.R.C. Groves, 'This air business' (n.d. [1939]), 4. Groves also wrote the rather florid covering note for the War Cabinet: Groves papers, 5(e), Groves, 'This air business', 39. On Groves's friendship with Sykes, see Ash, Sir Frederick Sykes and the Air Revolution, 14, 79, 125.

${ }^{41}$ Groves's own account of this period is given in Groves, Behind the Smoke Screen, 224-7. See also Peter V. James, 'Britain and airpower at Versailles, 1919-1920', International History Review, 5 (1983), 39-59.

${ }^{42}$ Letter from P.R.C. Groves to J.E.B. Seely, 10 September 1919, in Documents on British Foreign Policy, 1919-1939, ser. 1, vol. 1, no. 56. 
with the policy which was still being pursued that there was nothing for it but to resign my commission and make a public protest' ${ }^{43}$

That protest soon materialised in the form of Groves's week-long series of articles in The Times in March 1922, commissioned by its proprietor Lord Northcliffe-Rothermere's even more airminded elder brother-prominently placed and supported by leading articles. ${ }^{44}$ In the first article, Groves argued that the coming of aviation, and the subsequent and continuous improvement of the range, payload and speed of aircraft, had revolutionised the character of war: the theory of the knock-out blow from the air. Modern production methods enabled the creation of enormous fleets of aircraft. Therefore, at the start of the next war,

Each side will at once strike at the heart and nerve centres of its opponent; at his dockyards, arsenals, munitions factories, mobilization centres, and at those nerve ganglia of national moral-the great cities. The air raids of the past are no guide as to the nature of future aerial attack, or even of that which could be delivered to-day.

Groves was content to let his readers imagine the resulting carnage for themselves: 'There is no need to enlarge upon the results of aerial bombardments with high explosive, incendiary, and poison gas, delivered by thousands of bombers. To

\footnotetext{
${ }^{43}$ Groves papers, 5(e), Groves, 'This air business', 46-7. See also Groves, Behind the Smoke Screen, 259, 265.

${ }^{44}$ Groves papers, 5(e), Groves, 'This air business', 46-7. On Northcliffe and aviation, see Paris, Winged Warfare, 66-71.
} 
picture such action taking place simultaneously, or almost so, upon all the nerve centres of a State is to realise what is meant by a "war of areas", as opposed to the war of fronts which had characterised the recent fighting. He argued that it would be prohibitively expensive to scale up the inefficient air defences of 1917 and 1918 to cover the whole country against the much bigger air forces of the future. Therefore offence was the only possible defence, 'the policy of the aerial offensive-defensive, for which the weapon is the long-distance Striking force consisting of bombing machines'. And it was just such a force which Britain lacked, relying as it did upon a small, professional air force, unlike European air forces which could draw on conscripts or, crucially in Groves's view, civil aviation. France, he argued, appreciated the value of civil aviation as an adjunct to military aviation, as demonstrated by a generous system of state subsidies. So, more ominously, did Germany. ${ }^{45}$

In his second article, Groves introduced the concept of convertibility: ‘An aeroplane which can carry a certain number of passengers a certain distance at a certain speed is capable of carrying an equivalent weight in bombs for the same distance at the same speed; and any passenger-carrier which is efficient as such can be transformed into an efficient bomber'. Groves sketched in some detail the

\footnotetext{
${ }^{45}$ The Times, 21 March 1922, 13-4. All of Groves's March 1922 articles (except an anonymous one of $18 \mathrm{March}$ ), others he published later that year, and various reactions in the British press are reprinted in P.R.C. Groves, Our Future in the Air: A Survey of the Vital Question of British Air Power (London, 1922).
} 
history of the Allies' deliberations on the fate of Germany's civil aviation industry. He pointed out that the Supreme Council was warned of the danger of the commercial bomber as early as March 1919, and that the Washington Naval Conference, which concluded in February 1922, had formally taken notice of the convertibility problem. ${ }^{46} \mathrm{He}$ also described the systematic evasions by German companies and authorities in response to Allied attempts to monitor the ban on aircraft manufacture, and claimed that the 'camouflaged but still all-powerful German militarists' were eagerly awaiting the end of control in order to begin rebuilding German 'airpower, the key weapon of the future, in guise of civil aviation'. But despite, or rather because of, his experience with the control regime, Groves did not suggest attempting to prevent this resurgence. Instead he returned to and extended the Sykes plan, arguing that Britain should also use convertibility to build up a large fleet of civil aircraft to use as the basis for its striking force in wartime. The RAF would only provide fighter escorts and a small proportion of bombers, to provide 'cohesion and leadership' ${ }^{47}$ But, Groves alleged in his third article, so far from nurturing civil aviation the Air Ministry was ignoring it, with the military share of its budget continually increasing in adherence to an 'archaic militarist policy'. He sarcastically noted the contradiction between Britain's alert foreign policy and its neglectful air policy: 'In other words, German civil aviation,

\footnotetext{
${ }^{46}$ See Carlton, 'The problem of civil aviation', 308; Carolyn J. Kitching, Britain and the Problem of International Disarmament, 1919-34 (London and New York, 1999), 56-7.

47 The Times, 22 March 1922, 13-4.
} 
apparently, is likely to be of value to that country in the event of war; but British civil aviation is, or rather would, if it existed, be of no value to this country for military purposes'. ${ }^{48}$ Groves could see no other way for Britain to maintain a striking force on the scale that European air forces would soon possess than to emulate Germany and build up a strong civil aviation industry, to provide the basis for a convertible air fleet.

\section{The commercial bomber and the Home Defence Air Force}

Groves's articles were discussed widely. In part this was due to the patronage of the airminded but ailing Northcliffe. His newspaper printed Groves's articles, endorsed his conclusions in leading articles published at the start and at the end of his series, and then provided a platform for further broadsides from Groves over the next year. ${ }^{49}$ Another reason was his startling revelation of the huge size planned for the French air force: 220 squadrons by the end of 1923, compared with just twelve in Britain. Groves himself was a Francophile and always took pains to justify France's airpower in terms of the threat posed to it by the military potential of German civil aviation. But given the widespread distrust of France following the disillusionment with the Versailles settlement, the idea of a French

\footnotetext{
48 The Times, 23 March 1922, 13-4.

49 The Times, 21 March 1922, 13; The Times, 27 March 1922, 13; Groves papers, 5(e), Groves, 'This flying business', 47.
} 
air threat was more credible than a German one, commercial bombers or no. ${ }^{50}$ The self-evidently anaemic state of Britain's airlines also lent power to Groves's arguments: the only ones still flying after a number of collapses in 1920 and 1921 were already being sustained by temporary state subsidies, leading to pressure to make them permanent. ${ }^{51}$ Groves's articles came between a conference organised by the Air League of the British Empire in February, at which its head, Sir Sefton Brancker, attacked the government for allowing other countries to take the lead in civil aviation, and Sykes's resignation as Controller of Civil Aviation in April, in frustration over his department's shrinking budget. ${ }^{52}$

Other newspapers followed the lead given by The Times. The conservative Observer charged that the government's neglect of airpower meant 'An empire on sufferance', particularly noting the failure to support civil aviation-'The supreme blunder':

Civil aviation, which should hold indispensible reserves for emergency, has been virtually left to the cold mercies of economic supply and demand, and, if matters go as they are now doing, will be drawn blank as a resource

\footnotetext{
${ }^{50}$ John Ferris, 'The theory of a "French air menace": Anglo-French relations and the British Home Air Defence programmes of 1921-25', Journal of Strategic Studies, 10 (1987), 62-83.

${ }^{51}$ Higham, Britain's Imperial Air Routes, 42-6.

52 Pirie, Air Empire, 59-62; Sykes, From Many Angles, 299-300. Brancker was chosen as Sykes's replacement.
} 
of national protection. ${ }^{53}$

The aviation trade weekly Flight agreed completely with Groves 'that aerial preparedness on any other basis than that of a "striking force," the main body of which is fed by Civil Aviation, is quite impracticable, and would involve the expenditure of absurd sums'. ${ }^{54}$ Other technical publications such as Motor News and The Engineer called for the government to act on Groves's proposals, which were also noted in Parliament with approval by Seely, his former political master. ${ }^{55}$ So great was the public's interest in his articles that in the summer of 1922 Groves was able to publish a pamphlet of press responses under the title Our Future in the Air. ${ }^{56}$

The idea of convertibility began to spread. Businessman George Holt Thomas, a CATC member whose diverse civil aviation enterprises had collapsed in 1920, endorsed the concept in a letter to The Times; in September Lord Robert Cecil used it to justify his call in the League of Nations Assembly for an international air force. ${ }^{57}$ By June, the cumulative effect of the press attention being

53 Observer, 26 March 1922, 12.

${ }^{54}$ Flight, 30 March 1922, 183.

55 The Engineer, 31 March 1922, and Motor News, 1 April 1922, quoted in Groves, Our Future in the Air, 93-9; Parliamentary Debates (Commons), 152, 21 March 1922, 314-7.

${ }^{56}$ Groves, Our Future in the Air.

${ }^{57}$ The Times, 2 May 1922, 8; Carlton, 'The problem of civil aviation', 309. On Holt Thomas, see Peter Fearon, 'The growth of aviation in Britain', Journal of Contemporary History, 20 (1985), 21-40. 
paid to Britain's aerial danger produced a minor panic, in the style of the pre-war dreadnought and airship panics. ${ }^{58}$ Conservative newspapers and MPs hammered Lloyd George's government over the country's lack of aerial defences, the first of what became an almost annual occurrence for the rest of the decade and beyond. ${ }^{59}$ After the thirty-two-squadron Home Defence Air Force was announced in August, The Times proclaimed victory - even though there was still no provision for convertibility. ${ }^{60}$ Groves later claimed that he and the press had forced the government to expand the RAF, although it appears more likely that his campaign had, at most, brought forward the announcement of measures already planned. ${ }^{61}$

${ }^{58}$ See A.J.A. Morris, The Scaremongers: The Advocacy of War and Rearmament, 1896-1914 (London, 1984), 177-84; Alfred Gollin, The Impact of Air Power on the British People and their Government, 1909-14 (Stanford, 1989), 49-60, 230-60.

${ }^{59}$ Powers, Strategy Without Slide-rule, 141-3; Holman, 'The air panic of 1935'.

${ }^{60}$ The Times, 4 August 1922, 13.

${ }^{61}$ Groves, Behind the Smoke-screen, 20; Ferris, 'French air menace'; Ferris, Men, Money and Diplomacy, 129-30. 


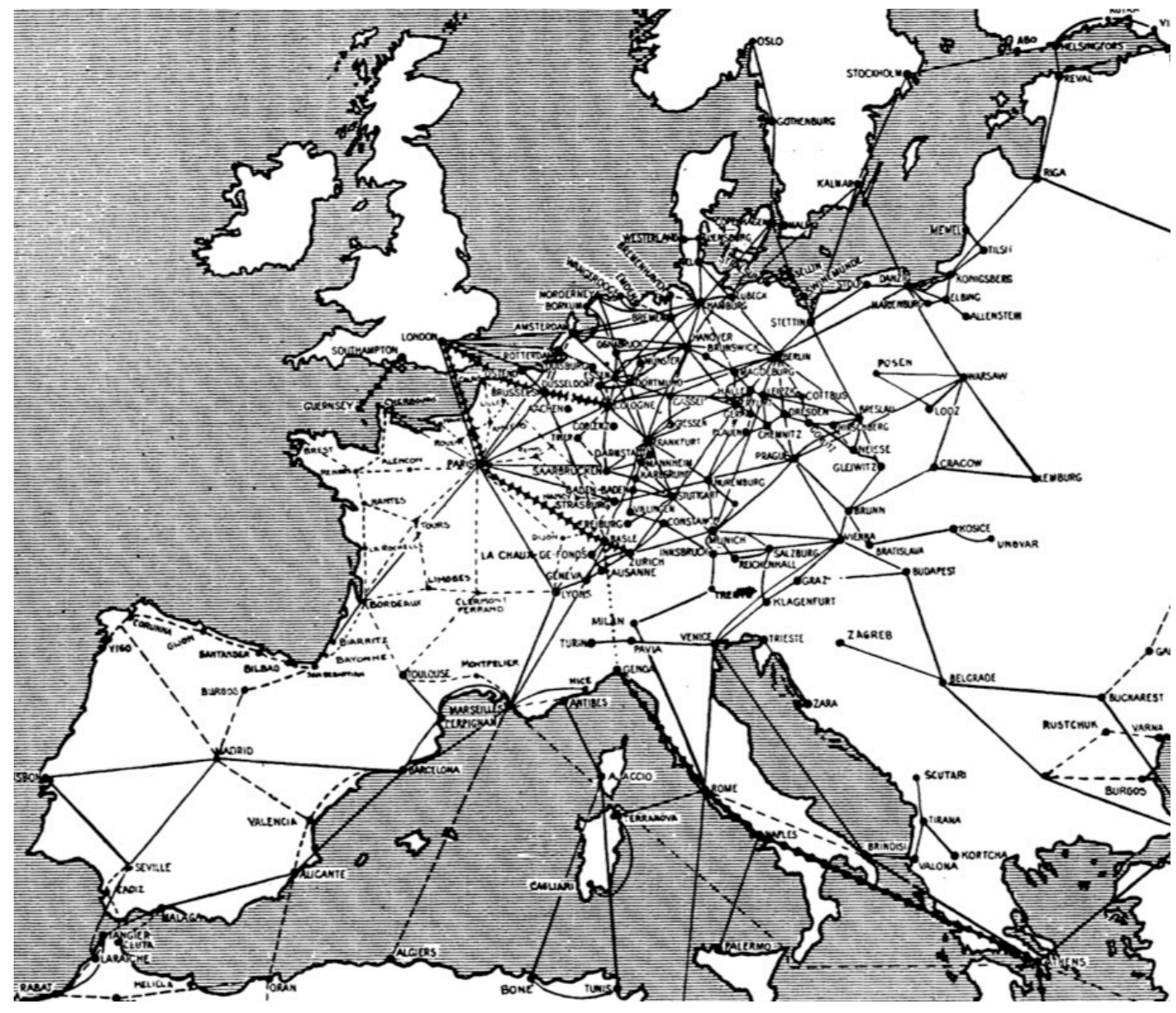

Figure 1. European air routes, June 1929. Note the relative density of German and British routes. Source: P.R.C. Groves, 'The influence of aviation on international affairs', Journal of the Royal Institute of International Affairs, 8 (July 1929), 289-317.

The rhetorical value of the commercial bomber to airpower advocates was that it multiplied the aerial threat posed by a disarmed Germany. So when Lord Halsbury, a wartime bombing expert, penned an alarming article for the Daily Mail entitled 'The poison gas war that is coming', he made sure to give a prominent place to Germany's potential commercial bombers. ${ }^{62}$ He wrote this in

${ }^{62}$ Daily Mail, 8 July 1927, 10. On Halsbury, see Neville Jones, The Origins of Strategic Bombing: A Study of the Development of British Air Strategic Thought 
1927, two years after the Locarno treaty and the year before the Kellogg-Briand pact, when Germany was to all appearances disarmed and docile. No matter how thoroughly disarmed it appeared to be, the commercial bomber meant that its strong civil aviation industry could always be portrayed as a menace to Britain and used as a justification for aerial rearmament. By the late 1920s, Germany's aircraft manufacturers, Junkers foremost among them, had secured a strong position in airliner exports. Its network of air routes was highly developed (see Figure 1), second in extent only to that of the United States: in 1929, Groves-now Secretary-General of the Air League of the British Empire-calculated that German airliners were flying a total of 45,000 miles each day, far exceeding the total for British airliners of only 5000 miles, including imperial routes. ${ }^{63}$ Government statistics told much the same story: in the nine months from April 1926, for example, more than 56,000 people were carried by German airlines, whereas the equivalent figure for Britain was little more than $15,000 .{ }^{64}$ When coupled to the commercial bomber concept, such disparities enabled Groves and others to argue that Britain was now in extreme peril, irrespective of the current realities of

and Practice upto 1918 (London, 1973), 142-7.

${ }^{63}$ P.R.C. Groves, 'The influence of aviation on international affairs', Journal of the Royal Institute of International Affairs, 8 (July 1929), 289-317, at 290.

${ }^{64} \mathrm{Cmd}$. 2844, 32, 53. On the use and abuse of civil aviation statistics from the inter-war period, see Gordon Pirie, 'Passenger traffic in the 1930s on British imperial air routes: refinement and revision', Journal of Transport History, 25 (2004), 66-84. 
disarmament and diplomacy.

\section{Disarmament and civil aviation}

The threat from commercial bombers was, however, also of great rhetorical use to pacifists and internationalists. In the later 1920 s and early 1930 s, convertibility became intimately linked with the questions of disarmament and rearmament, the future of collective security and of the Versailles settlement. That commercial bombers posed a serious problem for any multilateral disarmament process was recognised by Philip Noel Baker in his exhaustive and influential study Disarmament. Noel Baker, a professor of international relations at the University of London and a veteran of the early years of the League of Nations, believed that aviation might well be the crux of the whole disarmament problem. He gave two reasons for this: the first was that a knock-out blow from the air was now the quickest way to win a war; the second was the possibility of conversion. Even 'if everything were done that can be done short of abolition of aviation, commercial aircraft would still remain available for offensive military action of a peculiarly devastating kind', he argued. Civil aviation's 'very existence thus remains a grave menace to the world'. ${ }^{65}$

Noel Baker's concerns about the effect of convertibility on disarmament were shared by a number of other writers, ranging from the popular to the abstruse.

${ }^{65}$ P.J. Noel Baker, Disarmament (1926; 2nd edn, London, n.d. [1927]), 240. 
For example, according to William McDougall, a leading psychologist,

A few swift commercial aeroplanes could, by the use of a comparatively small supply of bombs, practically destroy in a few hours the capital of an unprotected nation and reduce to chaos all the delicately balanced processes of its complex life. No international agreements, no visible disarmament, however world-wide, will guarantee nations against this contingency. ${ }^{66}$

In Pseudo-Security, an attack on disarmament and collective security, the prolific airpower writer J.M. Spaight, a senior civil servant in the Air Ministry, noted that 'The unscrupulous aggressor will be favoured, consequently, by a limitation of air armaments which leaves civil aviation untouched' ${ }^{67}$ In 1928, Alfred Barnes, a Labour Co-operative MP, declared to the House of Commons that 'provided the war mind knows that there is a civil [air] service capable of expansion and of being directed to military purposes ... the world will never be safe from war'; five years later, Sisley Huddleston, a British journalist based in France, lamented in a diatribe against Versailles that 'Machines which should carry passengers are designed to carry bombs' ${ }^{68}$ Even novelists began to incorporate the idea of convertibility into their plots. ${ }^{69}$

\footnotetext{
${ }^{66}$ William McDougall, Janus: The Conquest of War (London, n.d. [1927]), 77.

${ }^{67}$ J.M. Spaight, Pseudo-Security (London, New York and Toronto, 1928), 109.

${ }^{68}$ Parliamentary Debates (Commons), 214, 12 March 1928, 1612; Sisley

Huddleston, War Unless- (London, 1933), 199.

${ }^{69}$ Michael Arlen, Man's Mortality: A Story (London, 1933); Frank McIlraith and
} 
The prescriptions varied somewhat, however. Noel Baker believed that the only answer to the problem of the commercial bomber was 'a system of mutual guarantee, depending largely on aircraft for its effect'.${ }^{70}$ Similar and often more far-reaching plans for an international air force or a world airline won widespread support, especially among left and liberal internationalists. ${ }^{71}$ By contrast, writers who like Spaight were further to the right tended to think that such far-reaching internationalisation was simply impossible in an age of resurgent nationalism. ${ }^{72}$ Hence, for Spaight, the commercial bomber threat was ultimately an argument against disarmament and collective security. But even Stanley Baldwin, the Conservative leader and Lord President of the Council, in the famous speech where he proclaimed that 'the bomber will always get through', allowed that 'in civil aviation there are the potential bombers' and so hoped that it would be possible to 'control civil aviation'. ${ }^{73}$ By the early 1930 s the commercial bomber

Roy Connolly, Invasion From the Air: A Prophetic Novel (London, 1934); S. Fowler Wright, Prelude in Prague: A Story of the War of 1938 (London, 1935). On fictional representations of the knock-out blow, see Martin Ceadel, 'Popular fiction and the next war, 1918-1939' in Frank Gloversmith (ed.), Class, Culture and Social Change: A New View of the 1930s (Brighton, 1980), 161-84.

${ }^{70}$ Noel Baker, Disarmament, 244.

${ }^{71}$ Holman, 'World police for world peace'; Zaidi, 'Aviation will either destroy or save our civilization'.

72 Spaight, Pseudo-Security, 112.

${ }^{73}$ Parliamentary Debates (Commons), 270, 10 November 1932, 636. Baldwin was deeply concerned about the danger of bombing: see Fleming, 'Cabinet government, British imperial security, and the World Disarmament Conference', 
appeared frequently and almost inevitably in serious discussions of the disarmament question as a problem which had to be acknowledged but not, it was hoped, an insoluble one. ${ }^{74}$

The long-anticipated World Disarmament Conference at Geneva, which opened in February 1932, brought the problem of convertibility to the fore. Several nations presented plans for the internationalisation of both military and civilian airpower. Most notably, France's war minister André Tardieu submitted a proposal forbidding national construction and ownership of long-range civilian aircraft as well as military ones, reserving these for international control. ${ }^{75}$ Britain wanted an agreement to ban strategic bombing, but not to give up its own imperial policing aircraft; moreover, it viewed the Tardieu plan with suspicion, seeing it as both impractical and hypocritical. ${ }^{76}$ The Air Ministry responded by way of

\section{$70-1$.}

${ }^{74}$ For further examples, see Victor Lefebure, Scientific Disarmament (London, 1931), 35ff, 277ff; C.C. Turner, Britain's Air Peril: The Danger of Neglect, Together with Considerations on the Role of an Air Force (London, 1933), 9, 122; Norman G. Thwaites, The Menace of Aerial Gas Bombardment (London, 1934), 15.

${ }^{75}$ Zaidi, 'Aviation will either destroy or save our civilization'. On the Conference, see Kitching, Britain and the Problem of International Disarmament, 140-73; Zara Steiner, The Triumph of the Dark: European International History 1933-1939 (Oxford, 2011), 31-45.

${ }^{76}$ For contrasting perspectives on the British and French positions on aviation at the Conference, see Meilinger, 'Clipping the bomber's wings'; Thomas R. Davies, 'France and the World Disarmament Conference of 1932-34', 
Spaight's An International Air Force, which suggested that international control might even make it 'easier for an unscrupulous Power to organise an overwhelming coup in the air' since it could manipulate flight schedules in order to amass a 'concentration of a formidable fleet of machines against an unsuspecting State'. ${ }^{77}$ Spaight's attack did little to dampen interest in the Tardieu plan in Britain, but Hitler's withdrawal of Germany from the Conference and the League of Nations in October 1933 removed any chance that any proposal attempting to limit the potential abuse of civil aviation would be adopted. The commercial bomber was not forgotten by disarmament advocates, but they now had bigger problems to deal with. ${ }^{78}$

\section{Rearmament and civil aviation}

The failure at Geneva did nothing to diminish the perceived threat of the commercial bomber in the short term. As Germany was evidently now intent on

Diplomacy and Statecraft, 15 (2004), 765-80; Fleming, 'Cabinet government, British imperial security, and the World Disarmament Conference'.

${ }^{77}$ J.M. Spaight, An International Air Force (London, n.d. [1932]), 74. For the Air Ministry's influence on Spaight, one of its civil servants, see Zaidi, 'Aviation will either destroy or save our civilization', 158. On the Air Staff's opposition to the Tardieu Plan and the degree to which it influenced the Cabinet's position, see Fleming, 'Cabinet government, British imperial security, and the World Disarmament Conference'.

${ }^{78}$ For a late discussion of the convertibility problem and disarmament, see 'Antiair raid precautions', Spectator, 20 September 1935, 414-5. 
rearming in the air as well as on land and sea, the airpower debate in Britain also began to shift towards rearmament. In July 1934, the National Government headed by Ramsay MacDonald-an avowed pacifist-announced the first RAF expansion programme since 1923. Talk of war increased: press campaigns and the first Empire Air Day gave a new prominence to the bomber in national life, while fears about poison gas attacks from the air were linked to allegations of secret German experiments in the London Underground. ${ }^{79}$ But whereas liberal and left internationalists still usually proposed dealing with the problem with enhanced forms of collective security, military intellectuals of a more conservative inclination argued that international co-operation was only going to get harder, and so each nation should look to its own defences.

Once again, the most influential of these was Groves, who returned to the fray early in 1934 with his magnum opus, Behind the Smoke Screen. ${ }^{80}$ Here he claimed vindication because his ideas about the convertibility of civil aviation,

\footnotetext{
${ }^{79}$ Holman, 'The air panic of 1935'; Martin Hugh-Jones, 'Wickham Steed and German biological warfare research', Intelligence and National Security, 7 (1992), 379-402.

${ }^{80}$ Groves, Behind the Smoke Screen. The mark of this book's influence is the way in which it was widely cited as authoritative on the nature of aerial warfare, even by those who vehemently disagreed with its politics and its conclusions; see, for example, Norman Angell, The Menace to Our National Defence (London, 1934); Jonathan Griffin, Britain's Air Policy: Present and Future (London, 1935); Philip S. Mumford, Humanity, Air Power and War: An Essay upon International Relations (London, 1936).
} 
though rejected by the government more than a decade earlier, were now commonplace. Groves bombarded the reader with facts and figures supporting his contention that since 1922 Britain's civil aviation industry had, if anything, fallen even further behind those of its rivals, to sixth place after the United States, Germany, France, Italy and the Netherlands. ${ }^{81}$ 'In the long run', he concluded, 'the only safe and reliable foundation of national air power lies in commercial air development': this would guard against the danger of a 'national Government of the Left' unilaterally abolishing its own air force. ${ }^{82}$ For Groves, for Britain to lead the world in civil aviation was vital to its security.

Groves's bitterness aside-one chapter was entitled, simply, 'J'accuse'-he was right to claim that the convertibility problem was now widely recognised. It was, for example, used to great effect by Churchill, ironically the man who had killed the Sykes memorandum fifteen years earlier. Now a bank-bench Conservative MP, he opened his campaign for aerial rearmament with a powerful speech in the House of Commons on 28 November $1934 .{ }^{83}$ Here Churchill alleged that Germany already had an 'illegal air force [which] is rapidly approaching equality with our own', predicting that this point would be reached within a year's

${ }^{81}$ Groves, Behind the Smoke Screen, 237.

${ }^{82}$ Groves, Behind the Smoke Screen, 230.

${ }^{83}$ On the start of Churchill's aerial rearmament campaign, see Martin Gilbert, Winston S. Churchill (London, 1976), vol. 5: 1922-1939, 550-9, 565-79; R.A.C. Parker, Churchill and Appeasement (London, Basingstoke and Oxford, 2000), 38-47. 
time. ${ }^{84}$ But when it came to 'the second line-civil aircraft which are capable of being used for military operations ... the story is very much worse for us':

Germany already has between 200 and 300 machines of long range with great speed, 220 to 230 miles an hour, which are now ostensibly employed, or actually employed, many of them, in carrying mail bags and to some extent in carrying passengers, which machines can be converted into longdistance bombers of the highest efficiency in a few hours. All that is necessary is to remove some parts of the passenger accommodation and fit bomb racks in their place.

Noting that Britain had nothing like this number of potential commercial bombers available, Churchill predicted that 'by this time next year, taking both the military and the convertible civil aircraft into consideration, Germany will have a substantially stronger Air Force than we'. ${ }^{85}$ Thus he used the convertibility problem to intensify the claim for which this speech is usually remembered, that Germany would reach air parity with Britain by the end of $1935 .{ }^{86}$

Although Baldwin denied their truth, Churchill's claims forced him to

${ }^{84}$ Parliamentary Debates (Commons), 295, 28 November 1934, 866.

${ }^{85}$ Parliamentary Debates (Commons), 295, 28 November 1934, 867.

${ }^{86}$ Churchill had already spoken of the convertibility danger: Parliamentary Debates (Commons), House of Commons, 292, 30 July 1934, 2374-6. His informants on this issue appear to have been Air Commodore (retired) P.F.M. Fellowes and, more particularly, Desmond Morton of the Industrial Intelligence Centre: Gilbert, Churchill, 554, 557-8, 570. 
announce an acceleration of the RAF expansion programme begun earlier that year. ${ }^{87}$ But this did not stop the spread of alarm: six months later, for example, Kim, a regular columnist in the airminded and rightwing Saturday Review, claimed that Germany was now the strongest nation in Europe, thanks to its commercial bomber fleet. ${ }^{88}$ This anxiety threatened at times to turn to unreasoned panic: one aviation expert made the breathless claim that it would only take a few days to convert the passenger airship Graf Zeppelin into a 'death-dealing raider'. ${ }^{89}$ But by 1935 convertibility was widely accepted as a serious problem, and, given the failure of disarmament, one which now strengthened the case for air parity in the critical transition from disarmament to rearmament.

\section{The end of the commercial bomber threat}

The claim that airliners could easily and quickly be converted into bombers always had its critics. These were almost always airpower advocates themselves; very few pacifists argued that the threat of the commercial bomber was exaggerated, for the obvious reason that this would diminish their own arguments against war. The usual argument was that, whatever the apparent similarity in ideal performance characteristics between bomb-carrying and passenger-carrying aircraft currently,

\footnotetext{
${ }^{87}$ Parker, Churchill and Appeasement, 47-8; Wesley K. Wark, The Ultimate Enemy: British Intelligence and Nazi Germany, 1933-1939 (Oxford, 1986), 42. ${ }^{88}$ Saturday Review, 12 April 1935, 453-4. See generally Holman, 'The air panic of 1935 '.

${ }^{89}$ J.A. Sinclair, Airships in Peace and War (London, 1934), 287.
} 
these would actually diverge in future. One of the first to make this argument was Pick in his minority CATC statement: he argued that civilian aircraft would not in fact 'comply sufficiently closely' with military requirements to be 'effectively interchangeable' with 'warlike' types. ${ }^{90}$ In 1922, Groves encountered resistance along similar lines from C.G. Grey, the influential editor of the Aeroplane, and the former Secretary of State for Air Lord Weir. ${ }^{91}$ The attitude of the professionals in the RAF may fairly be judged by that of Air Commodore R.H. Clark-Hall, who argued in 1924 that civil aviation might one day prove a valuable reserve, but not yet. ${ }^{92}$ Critics multiplied in the 1930s. Frederick Handley Page, one of Britain's most successful aircraft manufacturers, argued that the introduction of supercharged engines gave military aircraft access to high speeds which were uneconomic for commercial operation: only relatively small airmail carriers would ever need to fly so fast. ${ }^{93}$ Flight reversed its earlier support for Groves, now suggesting that commercial bombers would be highly vulnerable against purposebuilt fighters and that adding external bomb-racks would increase aerodynamic drag such that their formerly 'outstanding performance will have dwindled to a

\footnotetext{
${ }^{90}$ Cd. 9218, 18.

91 The Times, 24 June 1922, 17; Aeroplane, 29 March 1922, 222-3; The Times, 28 June $1922,5$.

${ }^{92}$ R.H. Clark-Hall, 'The value of civil aviation as a reserve to the Royal Air Force in the time of war', Journal of the Royal United Service Institution, 59 (August 1924), 415-32.

93 Observer, 18 March 1934, 18.
} 
very ordinary figure'. ${ }^{4}$ Vernon Bartlett, writing in the liberal News Chronicle, went so far as to claim that converted airliners would be completely useless militarily. ${ }^{95}$ These critics claimed that Groves and other proponents of the commercial bomber were out of touch with the pace of the latest aeronautical developments.

While sceptics might lament that 'The nation has been taught to regard these so-called air-liners as potential bombers of devastating potentialities', their technical arguments did not succeed in undermining the idea of convertibility. ${ }^{96}$ Instead, the commercial bomber very quickly became irrelevant to both sides in the armament debate due to Hitler's revelation of the existence of the Luftwaffe in March 1935, falsely claiming for it parity with the RAF. This meant that attention shifted to the purely military balance in the air. As the defence critic Liddell Hart pointed out, due to the progress of aerial rearmament in both Britain and Germany the additional strength which might be provided by German civil aviation had became proportionately less important over time. ${ }^{97}$ Although some airpower writers such as L.E.O. Charlton still argued as late as the Sudeten crisis in 1938 that convertibility upset parity calculations and gave the advantage to the aggressor, the rapid and large increase in purely military air strength of both

\footnotetext{
${ }^{94}$ Flight, 7 February 1935, 137.

${ }^{95}$ News Chronicle, 3 December 1934, 10.

${ }^{96}$ Bernard Acworth, The Navy and the Next War: A Vindication of Sea Power (London, 1934), 23.

${ }^{97}$ Liddell Hart, Europe in Arms (London, 1937), 14.
} 
Britain and Germany made such arguments seem far less plausible than they had been three or four years earlier. ${ }^{98}$ With disarmament a dead letter and rearmament a reality, commercial bombers lost their rhetorical value and hence their place in the discourse about the knock-out blow from the air.

By the start of the Second World War the shadow of the airliner had vanished almost entirely. Only occasional mention was made of commercial bombers during the war: for example, Bernard Davy, an aviation historian, argued during the Blitz that convertibility was still the greatest danger in peacetime, as it could lead to a sudden knock-out blow. ${ }^{99}$ Hiroshima removed even this distant threat. The sheer power concentrated into a single atomic bomb signalled the end of massed bomber fleets in their hundreds or thousands: parity would soon come to be measured in terms of warheads, not airframes. ${ }^{100}$ The potential convertibility

${ }^{98}$ L.E.O. Charlton, G.T. Garratt and R. Fletcher, The Air Defence of Britain (Harmondsworth, 1938), 65. Unsurprisingly, Groves too was still warning 'that civil aviation is readily convertible to military purposes': P.R.C. Groves, letter, Daily Telegraph, 8 June 1938, quoted in Chilston, 'The rearmament of Great Britain, France, and Germany down to the Munich Agreement of 30 September 1938', in Veronica M. Toynbee (ed.), Survey of International Affairs 1938 (London, New York and Toronto, 1953), vol. 3, 526.

99 Bernard Davy, Air Power and Civilization (London, 1941), 179.

100 This change, too, was largely rhetorical until the mid-1950s, as atomic bombs were relatively weak compared with the later hydrogen bomb, and anyway depended upon bombers for delivery until the development of long-range ballistic missiles capable of carrying them. See generally Lawrence Freedman, The Evolution of Nuclear Strategy (1981; 3rd edn, Basingstoke and New York, 
of civilian aircraft no longer mattered. Even so, there were occasionally curious echoes of the commercial bomber, from 1950, when a secret Whitehall group worried about the possibility that the Soviet Union would try to launch a sneak atomic attack on Britain by airliner, to 2001 and al Qaeda's use of hijacked airliners as flying bombs against civilian and government targets in the United States. ${ }^{101}$

\section{Conclusion}

The commercial bomber turned out to be a mirage. No fleet of converted airliners ever blotted out the sky over London. Civilisation was not imperilled by the existence of civil aviation. Ultimately, the sceptics' argument that bombers and airliners would diverge in their essential characteristics was correct. In order to evade enemy air defences, military aircraft needed the ability to fly at speeds which would be uneconomical in a commercial context. In the 1920s and early 1930s, there was little effective difference between the speeds of airliners and bombers, especially since so many of the former had been converted from the latter. This began to change from the mid-1930s, however, with the introduction of technical innovations such as high-octane fuels. ${ }^{102}$ Furthermore, the need for

2003).

${ }^{101}$ Peter Hennessy, The Secret State: Preparing for the Worst 1945-2010 (2002; 2nd edn, London, 2010), xxxii.

${ }^{102}$ John D. Anderson, Jr., The Airplane: A History of its Technology (Reston, 
speed meant that bomber fuselages became increasingly streamlined and narrow. This was not a problem for bombs, but it was for passengers, as those flying in the post-war Avro Lancastrian airliner, derived from the highly successful Lancaster bomber, discovered to their discomfort. Conversely, bombers such as the Hudson which had their origins in successful civil designs performed, at best, indifferently in their military role.

But these essentially technological reasons-which only gradually became clear-were not why civil aviation disappeared from Britain's public discourse about the threat of a knock-out blow. The real reasons were military and political. As argued here, commercial bombers only had significant military value when national air forces were small or non-existent. Once general rearmament began in the mid-1930s, the danger posed by airliners turned into bombers was trivial when set next to that posed by the ever-increasing numbers of purpose-built bombers. The same was true of their rhetorical value. When German aircraft bombed Guernica in April 1937, few even noticed that they were militarised versions of the civilian Ju 52 airliner. ${ }^{103}$ The aerial arms race had moved on.

The commercial bomber was an important part of the discourse about aviation in Britain between the wars. The widespread acceptance of the idea of 2002), 260; Gavin Bailey, 'The narrow margin of criticality: the question of the supply of 100-octane fuel in the Battle of Britain', English Historical Review, 123 (2008), 394-411.

103 Corum, The Luftwaffe, 198. 
convertibility meant that even in its most pacific guise, the aeroplane was a threat to Britain and to civilization itself, and this was a threat which both militarists and pacifists were quick to exploit rhetorically. The combination of the knock-out blow from the air and the commercial bomber entangled civil aviation and military aviation: it was not possible to divide one from the other. In 1922, Groves used German civil aviation to bring the threat of Britain's aerial destruction from the future into the present; others followed in his footsteps over the next decade, until the mid-1930s when the reality of the Luftwaffe trumped the rhetorical usefulness of Lufthansa. By then the apocalyptic vision of Britain's destruction was entrenched, with all that entailed for disarmament, rearmament, and appeasement. The shadow of the bomber was, in part, the shadow of the airliner too. 